Information for citation:

Khudoley K. M. Otkaz ot ispolneniya resheniy mezhdunarodnykh sudebnykh organov po zashchite prav $i$ svobod grazhdan [Refusal to Implement the Decisions of the International Judiciary on Protection of the Citizens' Rights and Freedoms]. Vestnik Permskogo Universiteta. Juridicheskie Nauki - Perm University Herald. Juridical Sciences. 2017. Issue 38. Pp. 463-473. (In Russ.). DOI: 10.17072/1995-4190-2017-38-463-473.

UDC 340.131 .5

DOI: $10.17072 / 1995-4190-2017-38-463-473$

\title{
REFUSAL TO IMPLEMENT THE DECISIONS OF THE INTERNATIONAL JUDICIARY ON PROTECTION OF THE CITIZENS' RIGHTS AND FREEDOMS
}

\section{K. M. Khudoley}

Perm State University

15, Bukireva st., Perm, 614990, Russia

ORCID: 0000-0003-1805-0674

ResearcherID: E-3186-2016

Articles in DB "Scopus" / "Web of Science":

DOI: $10.17072 / 1995-4190-2015-2-29-40$

DOI: $10.17072 / 1995-4190-2016-34-391-401$

e-mail: kostya-hudoley@yandex.ru

Introduction: the article analyzes the relationship between the enforcement of the decisions of the European Court of Human Rights (ECtHR) and those of the Constitutional Court of the Russian Federation. Purpose: to examine the provisions of the federal legislation on the refusal to implement the ECtHR decisions, as well as the decisions of the constitutional courts concerning the place of the ECtHR judgments in national legal systems; to substantiate the illegality of the complete refusal to comply with the ECtHR decisions by the states being parties to the European Convention on Human Rights (ECHR). Methods: the methodological framework of the study is based on a set of methods of scientific cognition, including the dialectical method and general scientific methods (analysis, synthesis, induction and deduction). The author also uses some specific scientific methods (formal-legal, comparative law). Special attention is paid to comparative and system research methods. Results: the complete refusal to execute the ECtHR judgments contradicts the constitutional rights of citizens to judicial protection and the fundamental principle of international law pacta sunt servanda. Constitutional control over the decisions of the ECtHR not only means the conditional nature of the provisions of part four of Article 15 of the Constitution of the Russian Federation, but also stipulates the incursion of the Constitutional Court of the Russian Federation into the competence of the ECtHR on the interpretation of the provisions of the ECHR. Conclusions: the complete refusal to implement the decisions of the ECtHR in respect of measures of an individual nature (including payment of monetary compensation) in the territory of Russia is unacceptable. It seems to be correct that the competent state authorities can look for alternative ways of implementing the ECtHR judgments through the Constitutional Court of the Russian Federation performing constitutional interpretation or adjustment of the constitutional meaning of the normative act previously recognized as incompatible with the ECHR by the ECtHR decision and, also, through changing the subordinate regulation.

Keywords: Constitution; Constitutional Court; constitutional justice; European Court of Human Rights; European Convention for the Protection of Fundamental Rights and Freedoms; right to appeal; public authorities; decision; refusal to implement decisions 


\section{Information in Russian \\ ОТКАЗ ОТ ИСПОЛНЕНИЯ РЕШЕНИЙ МЕЖДУНАРОДНЫХ СУДЕБНЫХ ОРГАНОВ ПО ЗАЩИТЕ ПРАВ И СВОБОД ГРАЖДАН}

\section{К. М. Худолей}

Кандидат юридических наук, доцент кафедры конституционного и финансового права Пермский государственный национальный исследовательский университет 614990, Россия, г. Пермь, ул. Букирева, 15

ORCID: 0000-0003-1805-0674

ResearcherID: E-3186-2016

Статьи автора в БД «Scopus» / «Web of Science»:

DOI: $10.17072 / 1995-4190-2015-2-29-40$

DOI: 10.17072/1995-4190-2016-34-391-401

e-mail: kostya-hudoley@yandex.ru

Введение: в статье анализируются вопросы соотношения юридической силь решений ЕСПЧ и Конституциионного суда РФ. Цель: рассмотреть положения федерального законодательства об отказе от исполнения решений ЕСПЧ, а также решения конституционных судов о месте решений ЕСПЧ в начиональных правовых системах, обосновать неправомерность полного отказа государствами-участниками ЕКПЧ от исполнения решений ЕСПЧ. Методы: использовалась совокупность методов научного познания: диалектический метод, общенаучные методы познания (анализ, синтез, индукиия и дедукция) и также частнонаучные методь познания (формально-юридический, сравнительно-правовой). В ходе научного поиска особое внимание уделялось сравнительному, системному методам исследования. Результаты: полный отказ от исполнения решений ЕСПЧ противоречит конституционному праву граждан на судебную защиту и основополагающему принципу международного права pacta sunt servanda. Конституционный контроль в отношении решений ЕСПЧ не только означает условный характер положений ч. 4 cm. 15 Конституцуии РФ, но и обусловливает вторжение Конституц̧ионного суда РФ в компетенцию ЕСПЧ по толкованию положений ЕКПЧ. Выводы: полный отказ от исполнения решений ЕСПЧ в части мер индивидуального характера (в т. ч. по выплате денежной компенсации) на территории России является недопустимым. Как представляется верным, компетентные органы государственной власти могут искать пути альтернативного исполнения решений ЕСПЧ посредством осуществления Конституцуионным судом РФ конституциионного толкования или корректировки конституциионного смысла нормативного акта, ранее признанного несовместимым с ЕКПЧ по решению ЕСПЧ, а также посредством изменения подзаконного регулирования.

Ключевые слова: Конституция; Конституционный суд; конституционное правосудие;

Европейский суд по правам человека; Европейская конвенция по защите основных прав и свобод; право на обращение; органы государственной власти; решение; отказ от исполнения решений

\section{Introduction}

In Russia, unlike countries such as Ukraine, the law on the enforcement of the ECtHR decisions have not been adopted, and the ECHR judgments have not formally been assigned to the number of executive documents. Therefore, it is not surprising that our country is among the leaders in the unfulfilled decisions of the ECtHR. In 2014 it occupied the third place (1474) after Italy (2622) and Turkey (1500). However, by the end of 2015 the number of unfulfilled decisions had increased to 1,549 . The record among all the countries of the Council of Europe was the amount that Russia owed in 2014 1.879 billion euros ( $92 \%$ of all money owed by other countries), however, in which 1.866 billion euros are payments on the "Yukos case". The average time for execution of the ECtHR judgments in
Russia is 9.7 years - more than in other CoE member states. Not surprisingly, the federal budget for 2016 provides the costs of implementing the decisions of the ECtHR at a rate of only 600 million rubles (about 9 million euros), which is several times less than it is necessary to pay for the current year (including not only the amount of monetary compensation but also the penalty for their nonpayment) ${ }^{1}$. At the same time, according to the representatives of the authorities, Russia intends to enforce neither the decision on the Yukos case nor on other resonant cases, referring to their political and unconstitutional nature.

\footnotetext{
${ }^{1}$ On the Federal Budget for 2016: Federal Law of December 19, 2016 No. 3415-FZ. Rossiyskaya gazeta - Russian Gazette. 2016. 23 Dec.
} 


\section{Place of the ECtHR Decisions in the Legal Systems of Foreign Countries}

In order to resolve the issue of the legitimacy of the refusal to implement the ECtHR decisions by the national authorities of the CoE member states it appears to be important to study the foreign experience of a number of countries (Austria, Germany, Italy, Germany, Great Britain). In addition, judges of the Constitutional Court of the Russian Federation and legal scientists often referred to it in substantiating their positions on the supremacy of the Constitution of the Russian Federation over the decisions of the ECtHR.

With regard to the ECHR, Austria not only accepted its ratification obligations, but also incorporated it into Austrian constitutional law, including the relevant provisions in Article 9.1 of the Constitution ${ }^{1}$. Meanwhile, in the practice of the ECtHR and the Constitutional Court of Austria, there are discrepancies between the interpretation of the content of the fundamental rights and the boundaries of their limitations. For example, when Austria became a party to the Convention, it interpreted the provisions of Article 6.1 of the Convention in the sense that they guarantee that courts deal with all issues of civil and criminal law, except for public (administrative) law. However, the ECtHR began to follow a different interpretation in its practice.

The Constitutional Court of Austria in its decision of August 14, 1987, in its turn, noted: "When it became a party to the Convention, Austria could not agree to accept such consequences, and could not foresee that the European Court of Human Rights would develop such a broad interpretation of civil rights". However, the Constitutional Court of Austria subsequently stated that the recognition of the invalidity of the Austrian reservation implies that all principles of public hearings must also be observed in the administrative process [11, p. 4]. Apparently, the Constitutional Court of Austria found a way to harmonize the provisions of the national constitution and the decisions of the ECtHR in order to be able to execute the latter [1, p. 198].

Unlike Austria, where the ECHR is equal in legal force to the national constitution, the Federal Constitutional Court of Germany in the "Gergulu case" defined the provision of the Basic Law to be above the ECHR. In considering this case, the Federal Constitutional Court of Germany noted: the provisions of the Convention may not be taken into account if there is no other way to prevent violation of the legal principles of the Basic Law. The Con-

\footnotetext{
${ }^{1}$ The Constitution of Austria of October 1, 1920. Constitution of the States of Europe; ed. by L. A. Okun'kov. M., 2001. Vol. 1. Pp. 26-114.
}

stitutional Court stressed that in the sense of internal law the Constitution in principle has priority over international obligations, and in exceptional cases, the legislator may deviate from the requirements of international treaties to prevent the violation of fundamental constitutional principles. But at the same time, as the Constitutional Court of the Federal Republic of Germany pointed out, the German courts are in all cases required to take into account the decision of the ECtHR which relate to the cases already resolved by them, if they carry out a new trial of the case and are able to take this decision into consideration without violating the Basic Law².

According to V. D. Zorkin, there is no doubt that this legal position does not mean an automatic obstacle to the implementation of the ECtHR judgments in the territory of the Federal Republic of Germany [3]. As the judge of the FCC of Germany G. Lubbe-Wolff noted in this regard, the relevant legal positions confirm the supremacy of national law, proceeding from the state sovereignty, but do not mean denial by German courts of the international obligations binding on Germany [5, p. 40]. It is not surprising that, despite the circumstances of the "Gergulu case", the Naumburg Supreme Court of Justice initially refused to include the ECHR standards in the national legal order, and subsequently the Federal Constitutional Court of Germany determined the mechanism for implementing the ECtHR decisions and actually implemented them in the national legal system. The decision of the Supreme Land Court of Naumburg was reconsidered and the decision of the European Court of Human Rights, which conflicts with the national jurisprudence, was executed, which in 2009 was stated by the Committee of Ministers of the Council of Europe. Apparently, the Constitutional Court of Germany managed to come out of the delicate situation with honor, on one hand, it unequivocally pointed to the Strasbourg Court on the immutability of the state sovereignty, and on the other hand, confirmed the fulfillment of international obligations accepted by Germany.

The Constitutional Court of Italy, in many respects following the example of the FCC of Germany, determined the importance of the ECHR law and the decisions of the European Court of Human Rights for the national legal order, in two of its decisions on assessing the constitutionality of the act allowing the state to appropriately own property

\footnotetext{
2 The Decision of the Federal Constitutional Court of Germany of October 14, 2004. Available at: http://www.bverfg.de/ entscheidimgen.html (accessed 01.08.2017).
} 
without compulsory purchase procedures. The relevant decisions of the Constitutional Court were conditioned by the Decision adopted by the ECtHR on March 29, 2006 in the case of Scordino v. Italy. The Constitutional Court of Italy noted that, in the presence of a constitutional dispute over the application of the Convention's law, the Constitutional Court must verify the compatibility of the provisions of the Convention in the interpretation of the European Court of Human Rights with the provisions of the Constitution; any discrepancy between the domestic law and the Convention in the interpretation of the ECtHR should be considered as a violation of the regime of constitutional legality and the Constitution; no rule of international law can prevail over the basic principles of the Constitution; this control should be based on a reasonable compromise between the state's connection with international obligations on the basis of Article 117 of the Constitution and the protection of national constitutional interests ${ }^{1}$.

Subsequently, the Constitutional Court of the Italian Republic, in its decision of November 19, 2012 in case No. 264/2012, disagreed with the findings of the ECtHR on cross-border pension benefits (the judgment of May 31, 2011 in the case of Maggio \& Others vs. Italy). In particular, it pointed out that the contradiction between the protection provided by the ECHR and the constitutional protection of fundamental rights should be resolved in the direction of maximizing the guarantees and provided that the appropriate relationship with other interests protected by the constitution is met. However, even pointing to the "subconstitutional" nature of the ECHR, the Constitutional Court of Italy nevertheless recognized the non-constitutionality of national laws, in the application of which the ECtHR had previously found a violation of the ECHR, finding that Italy is obliged to align national legislation with the Convention in accordance with the interpretation in the decisions of the European Court of Human Rights.

In the UK, the earliest conflict between the ECtHR and the national constitutional review body is the precedent in the Boyle case. The ECtHR, in its ruling of February 25, 1997, outlined the violation of the principles of fair trial provided for by the Convention in the traditional work of British military tribunals. However, by its decision in the

\footnotetext{
${ }^{1}$ The Decisions of the Constitutional Court of Italy No. 348, 349 in 2007. Available at: http://www.cortecostituzionale.it/ ActionPagina_325.do (accessed 01.08.2017).
}

Boyle case, the House of Lords refused to recognize the requirements of the judgments of the European Court of Human Rights as a general precedent $^{2}$. Currently, the Supreme Court, which has been solely exercising constitutional review functions in the UK since 2009, has adopted a series of precedent decisions detailing the situations in which either the decision of the ECtHR should be partially or completely abandoned. Briefly, in the opinion of the Supreme Court of Great Britain, such a refusal is applicable in the following cases:

1. When it can reasonably be expected that in the near future the European Court of Human Rights will come to the same opinion as the British Court (Case $R$ (on the application of Gentle) v. Prime Minister [2008] UKHL 20).

2. The decision is taken by the British Court solely within the national discretion in accordance with the convention (Case In Re G (Adoption: Unmarried Couple) [2008] UKHL 38).

3. Relevant relations are governed by case law and the court intends to use its right to decide not in accordance with the position of the European Court of Human Rights (Case Rabone v. Pennine CareFoundation NHS Trust [2012] UCC OF THEC 2).

4. The Court attaches greater importance to the position of the legislator, which determines the balance of rights and interests in a different way than the European Court of Human Rights (Case R (on the application of the Animal Defenders International) v. Secretary of State for Culture, Media and Sport [2008] UKHL 15).

5. The position of the European Court of Human Rights is clearly outdated (Case $R$ (on the application of Quila) v. Secretary of State for the Home Department [2011] UCC OF THEC 48).

6. The precedents of the European Court of Human Rights are based on incomplete information, and the court is simply mistaken (the position of the court does not coincide with the fundamental aspects of substantive or procedural law) (Case Manchester City Council v. Pinnock [2010] UCC OF THEC 45).

7. The judgments of the European Court of Human Rights, even if they are adopted by the Grand Chamber and are the application of general principles to a particular case, should not be regarded as ultimately binding on British courts (Case $R v$ Horncastle [2009] UCC OF THEC 14).

\footnotetext{
${ }^{2}$ The Decision of the House of Lords of July 18, 2002 (R. v. Boyd). Available at: http://www.publications.parliament.uk/pa/ ld200102/ldjudgmt/jd020718/boyd-1.htm (accessed 01.08.2017).
} 
8. The judgments of the European Court of Human Rights are only "taken into account", and the adherence to these decisions is only possible if they do not contradict the fundamental material and procedural norms of national law (Case $R v$ Secretary of State for Justice, McGeoch $v$ the Lord of the Council [2013] UCC OF THEC 63).

However, it should be noted that neither in the UK, nor in other countries the possibility of refusing to implement the decisions of the ECtHR is not provided at the legislative level. Therefore, there is nothing surprising that, to date, the $\mathrm{CoE}$ Committee of Ministers has never stated the fact of nonenforcement of the ECtHR decisions. Most states prefer to ignore the decisions of the ECtHR silently, given that the only effective measure of responsibility for non-compliance with the decisions of the Strasbourg Court is only the suspension of the state's membership in the Council of Europe or exclusion from it. In cases where the respondent state could not comply with the ECtHR decision, it notified the Strasbourg Court and the Committee of Ministers of the Council of Europe that similar violations found in the ECtHR judgment will continue to exist until "the completion of domestic legislative reform" [10, p. 111], which can last for years. Currently, the only open conflict between the respondent states and the ECtHR is the failure in 2012 of the UK Parliament to enforce the Strasbourg Court decision in the case "Hirst v. the United Kingdom" and grant the right to vote to prisoners. British officials warned by the Committee of Ministers of the Council of Europe of failure to comply with this decision of the ECtHR repeatedly stated their unwillingness to participate in the construction of a single European space, including leaving the $\mathrm{CoE}$.

\section{Refusal to Implement the ECtHR Decisions under the Law of the Russian Federation}

The constitutional control over the ECtHR acts was initially introduced into the Russian legislation by amendments to Articles 43, 85 and 101 of the Federal Law No. 1 of July 21, 1994 "On the Constitutional Court of the Russian Federation". These provisions allowed for the appeal to the Constitutional Court of the Russian Federation about the verification of the constitutionality of normative acts in spite of the decision officially adopted by an interstate body for the protection of human rights and freedoms in which violations of human rights and freedoms are revealed in the Russian Federation. It was also stated that the court reviewed the case in connection with the adoption by the interstate body for the protection of human rights and freedoms of a decision in which violation of human rights and freedoms in the Russian Federation was found in the application of the law or some of its provisions. When the court concludes that the issue of the possibility of applying the relevant law can be resolved only after confirmation of its compliance with the Constitution of the Russian Federation, it submits the request to the Constitutional Court of the Russian Federation on the verification of constitutionality of this law. These changes in the legislation on the Constitutional Court of the Russian Federation were conditioned by the legal positions that were expressed in the Ruling of the Constitutional Court of the Russian Federation of December 6, 2013 on the "second case of Markin"1 and did not yet provide for the complete refusal of the state to implement the decisions of the ECtHR.

However, on December 14, 2015, following the new decision of the Constitutional Court of the Russian Federation ${ }^{2}$, the amendments to the Federal Constitutional Law-1 were made that introduced a new power of the Constitutional Court to resolve the issue of the possibility to execute the decisions of the interstate body on protection of the rights and freedoms of the individual on the requests of the federal executive authority which is granted the power to provide protection of interests of the Russian Federation in consideration of the complaints filed against the Russian Federation in the interstate body on protection of the rights and freedoms of the individual. In fact, these provisions guarantee the right of the Constitutional Court of the Russian Federation to legalize the refusal to take measures not only of some general nature but also of the individual nature, including

\footnotetext{
${ }^{1}$ On the case of the examination of constitutionality of provisions of Article 11 and of paragraphs 3 and 4 of part four of Article 392 of the Civil Procedure Code of the Russian Federation in connection with inquiry of the Presidium of the Leningradsky District Military Court: The Decision of the Constitutional Court of the Russian Federation of December 6, 2013 No. 27-P. Collected Legislation of the Russian Federation. 2013. No. 50. Art. 6670.

${ }^{2}$ On the case of the examination of constitutionality of provisions of Article 1 of the Federal Law "On Ratification of the Convention for the Protection of Human Rights and Fundamental Freedoms and the Protocols thereto", paragraphs 1 and 2 of Article 32 of the Federal Law "On International Treaties of the Russian Federation", parts one and four of Article 11, paragraph 4 of part four of Article 392 of the Civil Procedure Code of the Russian Federation, parts one and four of Article 13, paragraph 4 of part three of Article 311 of the Arbitration Procedural Code of the Russian Federation, parts one and four of Article 15, paragraph 4 of part one of Article 350 of the Code of Administrative Procedure of the Russian Federation and paragraph 2 of part four of Article 413 of the Criminal Procedure Code of the Russian Federation in connection with the request of a group of deputies of the State Duma: The Ruling of the Constitutional Court of the Russian Federation of July 14, 2015 No. 21-P. Collected Legislation of the Russian Federation. 2015. No. 30. Art. 4658.
} 
the monetary payment of damages. It is obvious that the refusal from execution of measures of the individual nature can violate the universally recognized principle of international law (jus cogens) on the fulfillment of the accepted international obligations (pacta sunt servanda). At the same time in Russian legal literature there is an opinion (though not the only one) that the generally recognized principles of international law, as opposed to international treaties, have the legal effect which is at least equal to the Constitution (Part 1 Article 17 of the Russian Constitution is considered as the grounds) $[4$, p. 6]. But the Constitutional Court of the RF in the abovementioned decision of July 14, 2015 explained that according to Paragraph 1 of Article 31 of the Vienna Convention on the Law of Treaties, an international treaty is binding on its participants only if the meaning of the international treaty is clarified through the rules of interpretation set forth in the convention. Therefore, if in the course of the case the European Court of Human Rights interprets the Convention in violation of the above principles, the state has the right to refuse to enforce the judgment delivered against it.

We believe that the Constitutional Court of the Russian Federation, when issuing this decision, exceeded its authority, taking the place of the ECtHR as an official interpreter of the ECHR in violation of Article 46 of the ECHR, which Russia ratified without reservation: "The Russian Federation recognizes ipso facto and without special agreement the jurisdiction of the European Court of Human Rights binding on the interpretation and application of the Convention and the Protocols thereto in cases of alleged violation by the Russian Federation of provisions of these treaty acts when the alleged violation took place after their entry into force with respect to the Russian Federation"1. Moreover, the enforcement of the adopted judicial acts is an integral part of the judicial branch, therefore the Constitutional Court of the Russian Federation, while refusing to implement the decisions of the ECtHR, simultaneously encroaches on its authority as a judicial body for reviewing and resolving the categories of cases that are not under the jurisdiction of the national authorities.

The ECHR is a "living law" formed by the precedents of the ECtHR. Moreover, the decisions

\footnotetext{
${ }^{1}$ On Ratification of the "Convention for the Protection of $\mathrm{Hu}-$ man Rights and Fundamental Freedoms and the Protocols thereto": the Federal Law of March 30, 1998 No. 54-FZ. Collected Legislation of the Russian Federation. 1998. No. 14. Art. 1514.
}

of the ECtHR are a continuation of the act being interpreted, forming a single textual-logical and normative-interpretative integrity. Therefore, it is not possible to consider the provisions of the ECHR in isolation from the ECtHR judgments. The failure of the state to comply with the precedents established by the ECtHR is nothing more than a violation of the ECHR text itself. It does not represent a frozen abstract text adopted years ago, but acts as a legal substratum filled with concrete content by decisions of the official interpreter adapting the source text to legal realities. The ECHR, like many other fundamental international legal acts in the sphere of protection of fundamental human rights and freedoms, does not consist of regulative norms of law in the usual sense, but of legal principles of extremely broad content. Moreover, the implementation of these principles in specific legal relations is almost impossible with the understanding of their content by ordinary means of interpretation (grammatical, logical, etc.).

Therefore, having given the ECtHR the right to carry out an official interpretation of the ECHR, the Russian Federation simultaneously deprived itself of the right to provide mandatory clarification of the meaning of the provisions of the ECHR applicable in the consideration of the case of the alleged violation of its provisions by our state, unless, of course, the objectives of concluding the treaty can be established on the basis of context or other agreements referred to in Paragraph 1 Art. 31 of the Vienna Convention on the Law of Treaties. At the same time, Russia could have made a reservation at the time of joining the ECHR in the event of a change in the jurisprudence of the ECtHR in the future, but did not do so.

Many Russian scholars are increasingly criticizing the activities of the ECtHR, because it repeatedly refers in its decisions to "European consensus", which in its essence is nothing more than an international custom $[9$, p. 1730]. However, the requirements for universality established in Part 4 of Art. 15 of the Constitution of the Russian Federation virtually exclude the recognition of customary norms as part of the legal system of the Russian Federation, unless Russia itself recognizes their obligation. Moreover, the rules of conduct that have become customary for most countries of the Council of Europe are also difficult to classify as universally recognized norms of international law. This happens because according to the Resolution of the Plenum of the Supreme Court, only those rules accepted and recognized by the international 
community of states are legally binding, as a whole $^{1}$. However, the usual norms actually reflect the established standards in the legal regulation of certain relations based on legal principles arising from the nature of the ECHR. Unwillingness to comply with such standards raises reasonable assumptions that Russia does not intend for deep integration within the framework of a single European legal space in the field of protecting and observing human rights.

In addition, the Constitutional Court of the Russian Federation, in accordance with the latest changes in legislation, in fact, was granted the right to reconsider its own decisions, if the decision of the ECtHR comes into conflict with the earlier judicial act adopted by the Russian constitutional review body. Although, in general, the revision of decisions by the Constitutional Court of the Russian Federation is not allowed, since it would contradict its nature as a body of constitutional control, whose decisions are final. This circumstance was also pointed out by V. G. Yaroslavtsev, the judge of the Constitutional Court of the Russian Federation, in a special opinion on the "Yukos case": the decision of the ECHR contradicted in part the decision of the Constitutional Court of July 14, 2005 regarding the restoration of the limitation period for tax violations committed by dishonest taxpayers. Solving the issue of the possibility of execution of this decision on the territory of the country, the domestic constitutional court turned out to be a "judge considering his own case" ${ }^{2}$. As for the position of the Russian Constitutional Court that legitimate protection by prescient remedies has been granted only to bona fide participants in legal relations, we could object that the universal and Russian principles claim the opposite, since even a criminal hiding from investigative bodies is exempted from criminal responsibility in connection with the expiration of the statute of limitation.

Thus, the application by the Constitutional Court of the powers to verify decisions of international bodies for the protection of human rights creates the possibility for the Russian constitutional review body to intervene the competence of inter-

\footnotetext{
${ }^{1}$ On the Application by Courts of General Jurisdiction of Generally Recognized Principles and Norms of International Law and International Treaties of the Russian Federation: the Resolution of the Plenum of the Supreme Court of the Russian Federation of 10.10.2003 No. 5 (05.03.2013). Bulletin of the Supreme Court of the Russian Federation. 2003. No. 12.

${ }^{2}$ Special opinion of the Constitutional Court judge V. G. Yaroslavtsev. Official Internet portal of legal information. Available at: http://www.pravo.gov.ru (accessed 01.08.2017).
}

national bodies that interpret international conventions. While verifying the constitutionality of the decision of the Strasbourg Court, the Constitutional Court of the Russian Federation will have to interpret the decision by itself, and therefore, the provisions of the ECHR in the long run.

On March 15, 2016, the Venice Commission, in its pre-trial detention, criticized these amendments to Federal Law- $1^{3}$. In the opinion of this body, from Art. 3.2 of the law, the expression "the possibility of executing a decision" should be replaced by "compatibility with the Constitution of the Russian Federation of the means of executing an international decision". It is also necessary to delete articles according to which no actions can be taken to implement the international decision declared by the Constitutional Court to be inconsistent with the Constitution. The law should point to the obligation of the Russian authorities to find alternative ways of executing an international decision and clearly determine that the measures of an individual character set forth in the judgments of the European Court, such as the payment of just compensation, cannot be subject to an assessment of constitutionality.

Currently, the Constitutional Court of the Russian Federation has ruled that it is impossible to fully execute the decision of the European Court of Human Rights in the case of Anchugov and Gladkov v. Russia, which revealed a violation of the ECHR by a disproportionate ban in the Russian legislation on voting of persons serving sentences in places of deprivation of liberty. The RF Constitutional Court found it impossible to enforce the decision of the ECtHR in full on general measures, but admitted that the federal legislator has the right to transfer certain regimes of serving a sentence of deprivation of liberty (in particular, a settlement colony) to alternative punishments that do not entail restrictions on electoral rights ${ }^{4}$.

\footnotetext{
${ }^{3}$ Opinion on Law of Amendments to the Constitutional Law on the Constitutional Court of the Russian Federation (implementation of findings of international bodies for the protection of human rights and freedoms). Available at: http://www.venice.coe.int/WebForms/documents/by_opinion.aspx?lang=EN (accessed 01.09.2017).

${ }^{4}$ On the Case on the Resolution of the Question of the Possibility of Execution in Accordance with the Constitution of the Russian Federation of the Decision of the European Court of Human Rights of July 4, 2013 on the case "Anchugov and Gladkov v. Russia" in connection with the request of the Ministry of Justice of the Russian Federation: Decision of the Constitutional Court of the Russian Federation of April 14, 2016 No. 12-P. Rossiyskaya gazeta - Russian Gazette. 2015. April 20.
} 
Apparently, the Constitutional Court took certain steps towards the ECtHR, since it considered that the Russian legislator has the right (but not the obligation) to grant voting rights to some prisoners, but only exercising its sovereign rights, and not pursuant to directions of the ECtHR, whose decision on general measures Russia refused to comply with, as it was said above. This attempt at a compromise approximation of the positions of the courts can be considered positive, since it may lead to partial implementation of the ECtHR decision, but insufficient.

As pointed out by the Constitutional Court of the Russian Federation in the above decision, according to Art. 56 of the Criminal Code of the Russian Federation, punishment in the form of deprivation of liberty may be imposed on the convict who committed the first offense of minor gravity, only in the presence of aggravating circumstances, with the exception of crimes related to the narcotic drugs and psychotropic drugs trafficking, or only if the corresponding article of the Special Part of the Criminal Code is the only form of punishment ${ }^{1}$. However, even the Constitutional Court of the Russian Federation admitted that in 200636,128 people were convicted for committing crimes of a small degree of severity to imprisonment. In other words, $10 \%$ of all the convicted of crimes of low severity are sentenced to real imprisonment. According to the established practice of the ECtHR, the undifferentiated deprivation of the active electoral right of persons convicted of crimes punishable by imprisonment for less than 3 years (the judgment in the case of Scoppola v. Italy) is a violation of the ECHR. We assume the RF Constitutional Court could not overcome this discrepancy in the abovementioned decision.

In addition, the ECtHR considering the case of Anchugov and Gladkov v. Russia (as well as Scoppola v. Italy or Hirst v. Great Britain) faced a very unequivocal issue of depriving the right to vote of those persons who were sentenced to imprisonment for long terms, and not only those who were imprisoned for up to 3 years. It seems that in making the decision, the ECtHR drew attention to the general and undifferentiated restrictions on the active electoral right of all citizens deprived of their liberty by a court decision in the narrow sense of the word, not including forced labor, arrest or detention

${ }^{1}$ Criminal Code of the Russian Federation (Part One): the Federal Law of June 13, 1996 No. 63-FZ (as amended of 28.11.2015). Collected Legislation of the Russian Federation. 1996. No. 25. Art. 2954. in a disciplinary military unit. Therefore, it is hardly possible to completely agree with the statement of the Constitutional Court of the Russian Federation that the concept of "deprivation of liberty" as a form of criminal punishment does not comply in its content with that used in Paragraph 1 of Article 5 of the Convention for the Protection of Human Rights and Fundamental Freedoms.

It seems to us that persons serving a sentence in settlement colonies can vote in polling stations on the territory of the municipalities where the correctional institution is located on the basis of a special certificate issued by the head of the colonysettlement. We believe that such an order is more preferable than voting by mail, since the correspondence of persons serving a sentence of imprisonment is subject to censorship. Thus, it is not possible to fully ensure the secrecy of the voting of persons held in correctional institutions. We consider the formation of polling stations on the territory of the colony-settlement unacceptable because it is impossible to ensure the observance of the principle of free elections.

Subsequently, the Constitutional Court of the Russian Federation denied the possibility of enforcing the ECHR decision in the "Yukos case". As the Constitutional Court of the Russian Federation summarized, payment of monetary compensation from the budget system, which was awarded by the ECtHR to the former shareholders of the company that had built illegal schemes for tax evasion and that still owes the system 227 billion rubles, contradicts the constitutional principles of equality and justice in tax legal relations. However, like in the case of Anchugov and Gladkov, the Federal Constitutional Court granted the possibility of voluntary execution of the ECtHR decision, providing for the similar right of the Government of the Russian Federation in the event that new Yukos property is discovered and after settlement with creditors (primarily with the state). This right neither conditions should concern state revenues or expenses or property ${ }^{2}$. As it is easy to imagine,

\footnotetext{
${ }^{2}$ On the Case on the Resolution of the Question of the Possibility of Execution in Accordance with the Constitution of the Russian Federation of the Decision of the European Court of Human Rights of July 31, 2014 on the case "OAO Oil company YUKOS v. Russia" in connection with the request of the Ministry of Justice of the Russian Federation: the Decision of the Constitutional Court of the Russian Federation of January 19, 2017 No. 1-P. Official Internet portal of legal information. Available at: http://www.pravo.gov.ru (accessed 01.08.2017).
} 
the debts to the state in the amount of 227 billion rubles and the total absence of property to which penalty could be imposed completely exclude such execution of the ECtHR decision even as an act of goodwill.

\section{Results}

In the legal literature, it is noted that the ECHR does not stand above the Russian Constitution, as Art. 15 of the Basic Law establishes the lawful, but not the unconstitutional nature of international treaties $[6$, p. 260]. We should agree with this statement, but in our opinion, this fact does not at all mean the possibility of a complete refusal to implement the ECtHR decision by the national authorities, especially with regard to measures of an individual character. Do not forget about the rule fixed in Art. 27 of the Vienna Convention on the Law of Treaties, which prescribes the impossibility of refusing to comply with international treaties with the provisions of internal law, including the provisions of the Constitution. According to A. V. Dolzhikov, regarding the law enforcement aspect of the national legal system, the supremacy of the Constitution of the Russian Federation is conditional. Thus, the federal legislator does not finalize the ban on the priority of the international treaty in relation to the Basic Law of Russia, but only complicates the possibility of harmonizing the norms of the relevant treaty and the norms of the Constitution of the Russian Federation, for example, in the form of a constitutional interpretation [2, p. 13].

According to Art. 46 of the Constitution of the Russian Federation, everyone is guaranteed judicial protection of his rights and freedoms, including international bodies for the protection of human rights and freedoms, if all domestic remedies have been exhausted. As of now, the concept of "judicial protection" implies the recognition and enforcement of the decisions taken by the ECtHR, at least in recognition of the violation of rights and freedoms and payment of monetary compensation, but not ignoring them. Based on the provisions of Part 4 of Art. 15, Part 1 of Art. 17, Art. 18 of the Constitution of the Russian Federation, human rights and freedoms in accordance with generally recognized principles and norms of international law, as well as international treaties of the Russian Federation are directly applicable. However, the RF Constitutional Court decision No. 21-P of July 14, 2015 contains one very important observation. Any decision of the ECHR stating a violation of the ECHR by the Russian Federation can be enforced by Russian courts only after the constitutionality has been confirmed and its provisions have been implemented by the federal constitutional court in the legal system of Russia. It can be stated that the judgments of the ECtHR which establish violations of the ECHR by the Russian Federation are not automatically included in the legal system of Russia. Herein, in our opinion, lies a certain violation of Part 4 of Art. 15 and paragraph "d", Part 2 of Art. 125 of the Constitution of the Russian Federation. These stipulate that the ratified international treaties of the Russian Federation are a part of the legal system of Russia unconditionally, and constitutional control by the Constitutional Court of the Russian Federation is carried out only with regard to international treaties that have not entered into force before their ratification.

Thus, there is a conflict of the two constitutional values: on the one hand, state sovereignty and, as a consequence, the supreme legal force of the Basic Law of the Russian Federation (Part 1 and 2 of Article 4, Part 1 of Article 15 of the Constitution of Russia); on the other hand, a person and their rights, being the highest value in the state (Article 2 of the Constitution of the Russian Federation) in accordance with the generally recognized principles and norms of international law, as well as international treaties of the Russian Federation. In this regard, we can agree with A. von Bogdandy, who proposes to replace the issue of the hierarchy of the national constitution and international treaties with the question of weighing (balancing) conflicting constitutional values [8, p. 398]. Characterizing the constitutional conformist interpretation, K. Hesse noted the importance of the principle of practical harmonization: the meaning of the norm being interpreted should not be in conflict with other provisions of the Basic Law. Where there has been a conflict, it is inadmissible to deprive the subject of regulation of any constitutional provisions [12, p. 35]. In English jurisprudence, this principle of interpretation has been termed "concordant interpretation" [7, p. 412], and in the practice of the Supreme Court of the United States it is known as the Charming Betsy canon ("an act of Congress should never be interpreted so as to violate international law, if there remains any other possible construction"1). An example of the norms enshrining this method of interpretation is Art. 233 of the Constitution of the Republic of South Africa, according to which the court must give preference to any reasonable interpretation of legislation that is consistent with international

\footnotetext{
${ }^{1}$ Alexander Murray v. The Charming Betsy. United States Reports; ed. by. William Cranch. Vol. 6. P. 64.
} 
law, as compared to any alternative interpretation that contradicts it ${ }^{1}$.

Also, the position of the judge of the Constitutional Court of the Russian Federation K.V. Aranovsky seems to be right that the subject of the legal regulation of the Constitution of the Russian Federation and the ECtHR does not coincide fully, but only partially. The constitutionality of the national law does not at all exclude its simultaneous contradiction to the ECHR, and vice versa. Among other things, rather abstract formulations of both the Constitution of the Russian Federation and the ECHR allow for the possibility of their various interpretation. Both the Constitutional Court of the Russian Federation and the ECtHR have repeatedly changed their legal positions when considering similar cases. Therefore, the constitutional interpretation given by the Russian Constitutional Court when considering the case on the constitutionality of the law does not at all exclude another interpretation that will also comply with the Constitution of the Russian Federation. Therefore, the decision of the ECtHR contrary to the legal position of the Constitutional Court of the Russian Federation does not always mean unconstitutionality of such a decision, if it does not decide on it ${ }^{2}$.

In addition, the national legal system and the system of international law cannot exist in isolation from each other. Therefore, both the Constitutional Court of the Russian Federation should look for ways to implement the decisions of the ECtHR and the ECtHR should, in its practice, pay more attention to the peculiarities of national legal systems in which certain standards developed in the course of the ECtHR practice do not find fulfillment due to historical, cultural and other factors. An open conflict between the RF Constitutional Court and the ECtHR is unlikely to be of positive significance for Russia, since the refusal to enforce the ECtHR decisions against individuals will not be an obstacle to similar complaints from other applicants to the Strasbourg Court, which will consider these cases based on old precedents. For each unperformed decision of the ECtHR, penalties will be assessed. The reputational costs of Russia as a result of an open conflict with the Council of Europe, which may lead to the suspension of membership in this organization or even the exclusion from it, are not even discussed.

\footnotetext{
${ }^{1}$ South Africa - Constitution South Africa - Constitution, adopted: 8 May 1996 (as amended by Constitution Seventeenth Amendment Act, from 1 February 2013). Available at: http://www.uznal.org/constitution.php?text=South_Africa\&lan guage $=\mathrm{e}$ (accessed 01.08.2017).

${ }^{2}$ Special opinion of the Constitutional Court judge K. V. Aranovsky. Official Internet portal of legal information. Available at: http://www.pravo.gov.ru (accessed 01.08.2017).
}

\section{Conclusions}

The complete refusal to implement the ECtHR decisions in respect of measures of an individual nature (including payment of monetary compensation) in the territory of Russia is unacceptable. It seems to be correct that the competent state authorities can look for alternative ways of enforcing the ECtHR decisions through the Constitutional Court of the Russian Federation performing constitutional interpretation or adjustment of the constitutional meaning of the normative act previously recognized as incompatible with the ECHR by the ECtHR decision and, also, through changing the subordinate regulation.

\section{References}

1. Gracheva (Perchatkina) S. A. Konstitutsionnoe pravosudie i realizatsiya resheniy Evropeyskogo suda po pravam cheloveka: nauchno-prakticheskoe posobie [Constitutional Justice and Implementation of Decisions of the European Court of Human Rights: ScientificPractical Guide]. 2012. 240 p. (In Russ.).

2. Dolzhikov A. V. "Gordost' i predubezhdenie»: sorazmernost' polnogo konstitutsionnogo zapreta zaklyuchennym golosovat'v Rossii. Postanovlenie Evropeyskogo suda po pravam cheloveka ot 4 iyulya 2013 goda ["Pride and Prejudice": Proportionality of Blanket Constitutional Ban on the Right to Vote for Detained Persons in Russia. Judgment of the European Court of Human Rights of July 4, 2013]. Mezhdunarodnoe pravosudie - International Justice. 2013. Issue 4. Pp. 11-31. (In Russ.).

3. Zor'kin V. D. Predel ustupchivosti [Limit of Compliance]. Rossiyskaya gazeta - Russian Gazette. 2010. October 29. (In Russ.).

4. Kuznezova O.A. Yuridicheskaya sila obshchepriznannykh printsipov i norm mezhdunarodnogo prava $v$ rossiyskoy pravovoy sisteme [Validity of the Conventional Principles and Norms of International Law in the Russian Legal System]. Yuridicheskaya nauka $i$ pravoprimenitel'naya praktika - Jurisprudence and Law Enforcement Practice. 2009. Issue 3. Pp. 4-10. (In Russ.).

5. Lubbe-Wolff G. Evropeyskiy sud po pravam cheloveka $i$ natsional'nye sudy - delo Gergyulyu [The European Court of Human Rights and National Courts: Gorgulu Case]. Sravnitel'noe konstitutsionnoe obozrenie - Comparative Constitutional Review. 2006. Issue 1. Pp. 39-42. (In Russ.).

6. Khudoley D. M. Klassifikatsiya izbiratel'nykh sistem [Classification of Electoral Systems]. Vestnik Permskogo universiteta. Yuridicheskie nauki - Perm University Herald. Juridical Sciences. 2016. Issue 3 (33). Pp. 258-267. 
(In Russ.). DOI: 10.17072/1995-4190-2016-33258-267.

7. Betlem $G$. The Doctrine of Consistent Interpretation. Managing Legal Uncertainty. Oxford Journal of Legal Studies. Vol. 22. No. 3. Pp. 397418. (In Eng.). DOI: 10.1093/ojls/22.3.397.

8. Bogdandy A. von Pluralism, Direct Effect, and the Ultimate Say: On the Relationship between International and Domestic Constitutional Law. International Journal of Constitutional Law. 2008. Vol. 6. No. 3-4. Pp. 397-413. (In Eng.). DOI: $10.1093 /$ icon/mon015.

9. Dzehtsiarou K. European Consensus and the Evolutive Interpretation of the ECHR. German Law Journal. 2011. Vol. 12. Pp. 1730-1745. (In Eng.).

10. Gomien D., Harris D., Zvaak L. Law and Practice of the European Convention on Human Rights and European Social Charter. Council of Europe. Strasbourg, 1998. 480 p. (In Eng.).

11. Haller $H$. The Interplay between the Austrian Constitutional Court and the European Court of Human Rights. Proceedings of Conference on the Interaction of National Courts with $\mathrm{Eu}-$ ropean Courts (Batumi, Georgia, 6-7 November, 2007). Strasbourg, 2007. 100 p. (In Eng.).

12. Hesse $K$. Grundzüge des Verfassungsrechts der Bundesrepublik Deutschland. Heidelberg, 1999. 335 p. (In Germ.).

\section{References in Russian}

1. Грачева (Перчаткина) С. А. Конституционное правосудие и реализация решений Европейского суда по правам человека: науч.практ. пособие. М.: Ин-т законодательства и сравнит. правоведения при Правительстве РФ, КОНТРАКТ, 2012. $240 \mathrm{c}$.

2. Должсиков А. В. «Гордость и предубеждение»: соразмерность полного конституционного запрета заключенным голосовать в России. Постановление Европейского суда по правам человека от 4 июля 2013 года // Международное правосудие. 2013. № 4. С. 11-31.
3. Зорькин В.Д. Предел уступчивости // Российская газета. 2010. 29 окт.

4. Кузнецова О.А. Юридическая сила общепризнанных принципов и норм международного права в российской правовой системе // Юридическая наука и правоприменительная практика. 2009. № 3. С. 4-10.

5. Люббе-Вольфф Г. Европейский суд по правам человека и национальные суды - дело Гергюлю // Сравнительное конституционное обозрение. 2006. № 1. С. 39-42.

6. Худолей Д. М. Классификация избирательных систем // Вестник Пермского университета. Юридические науки. 2016. Вып. 33. C. 258-267. DOI: 10.17072/1995-4190-201633-258-267.

7. Betlem G. The Doctrine of Consistent Interpretation - Managing Legal Uncertainty // Oxford Journal of Legal Studies. Vol. 22, № 3. Pp. 397-418. DOI 10.1093/ojls/22.3.397.

8. Bogdandy A. von Pluralism, Direct Effect, and the Ultimate Say: On the Relationship Between International and Domestic Constitutional Law // International Journal of Constitutional Law. 2008. Vol. 6, № 3-4. Pp. 397413. DOI 10.1093/icon/mon015.

9. Dzehtsiarou K. European Consensus and Evolutive Interpretation of the ECHR // German Law Journal German Law Journal. 2011. Vol. 12. Pp. 1730-1745.

10. Gomien D., Harris D., Zvaak L. Law and Practice of the European Convention on Human Rights and European Social Charter. Council of Europe. Strasbourg, 1998. 480 p.

11. Haller $H$. The Interplay between the Austrian Constitutional Court and the European Court of Human Rights. Material of Conference on the Interaction of National Courts with European Courts (Batumi, Georgia 6-7 November 2007). Strasbourg, 2007. 100 p.

13. Hesse $K$. Grundzüge des Verfassungsrechts der Bundesrepublik Deutschland. Heidelberg, 1999. $335 \mathrm{p}$. 